AWEJ for Translation \& Literary Studies, Volume 5, Number3. August 2021

Pp. 101-112

DOI: http://dx.doi.org/10.24093/awejtls/vol5no3.8

\title{
Hailsham as an Intimate Space: A Bachelardian Reading of Kazuo Ishiguro's Never Let Me Go
}

Soumaya Bouacida

Department of Foreign Languages, University of $20^{\text {th }}$ August 1955, Skikda, Algeria

Corresponding Author: soumayabouacida@gmail.com

Ikram Lecheheb

Department of Foreign Languages, University of $20^{\text {th }}$ August 1955, Skikda, Algeria

Itidel Boumali

Independent Scholar, Skikda, Algeria

Nada Khlifa

Independent Scholar, Skikda, Algeria

Received: 4/29/2021

Accepted: 7/26/2021

Published: $8 / 25 / 2021$

\begin{abstract}
This paper aims to investigate the role played by Hailsham, the fictional boarding school in Kazuo Ishiguro's novel Never Let Me Go, in the mind of its central characters as seen through Gaston Bachelard's conception of space. The article then aims to explore how the memory of Hailsham works as a coping mechanism for some of the novel's characters, especially for Kathy. After a brief survey of Bachelard's spatial criticism, the article then discusses the elements of intimacy in the space of Hailsham and portrays the boarding school as a oneiric house or a childhood home in Bachelard's terms. By using an analytical method, this study offers an examination of two notions, that of memory and that of imagination, which are built upon the aspect of association and intimacy. Following the development of the plot of Never Let Me Go, the article sheds light on the role played by the so-called "cottages" in the shaping of these character's relations to themselves, to each other, and to the outside world. This paper opens the door to other critics to read Never Let Me Go from the perspective of other spatial theorists like Mitchel Foucault, Henri Lefevbre, and Edward Soja.

Keywords: Bachelard, cloning, imagination, intimacy, Kazuo Ishiguro, memory, Never Let Me Go, and Space

Cite as: Bouacida, S., Lecheheb, I., Boumali, I., \& Khlifa, N.(2021). Hailsham as an Intimate Space: A Bachelardian Reading of Kazuo Ishiguro's Never Let Me Go. Arab World English Journal for Translation \& Literary Studies 5 (3) 101-112.

DOI: http://dx.doi.org/10.24093/awejtls/vol5no3.8
\end{abstract}

Arab World English Journal for Translation \& Literary Studies 


\section{Introduction}

In his elaborate work entitled Poetics of Space, the influential French philosopher Bachelard (1994) investigates space from an original perspective. Unlike his peers, Michel Foucault, Henri Lefevbre and Edward Soja, who probe the concept of space as a social construct, Bachelard explores it from a psychological, and cognitive dimension. It is worth noting that the poetics of space offers a definitive diagnosis of how memory and imagination work in favor of one another to form the intimacy of space. Never Let Me Go, a dystopian science fiction novel written by the Japanese British writer Kazuo Ishiguro in 2005, can be read according to Bachelard's spatial patterns. The story of this novel is told by its main character, Kathy, who drives the story by returning to her childhood memories. Kathy uses her imagination and memory to revisit her most favorite space, Hailsham. Her memories have left her hollow and nostalgic as she longs for what once was but no longer existed. Everything reminds Kathy of her childhood home. Whenever she encounters places that resemble Hailsham, a mixture of sorrow and joy occurs in her imagination.

The object of this study is to examine this novel according to Bachelard's ideas on space, memory, and imagination. Reading Never Let Me Go in terms of spatiality is of a notable significance since it contributes to the already existing scholarship on Never Let Me Go. Studies on space in Never Let Me Go are less trodden; Critics have sparsely approached this novel from the standpoint of Bachelard'sPoetics of Space. Therefore, this study is original in the way it tackles the representation of space in Never Let Me Go from a Bachelardian perspective regarding memory and imagination. In framing a new angle of analysis, this paper problematizes how Hailsham is intimately perceived in Never Let Me Go by posing the following questions: How can Hailsham be interpreted according to Bachelard's cognitive study of space? In what sense can imagination and memory be explored in terms of space in the novel? How can memory and imagination be associated with each other?

Methodologically speaking, in exploring the core idea of the topic, this study relies on the argumentative and the analytical method of data estimation. Moreover, the research analysis is based mainly on the theorization of Gaston Bachelard Poetics of Space that embraces the notions of memory and imagination in terms of spatial interiority and the intimacy. Since Bachelard's piece is originally written in French, we have used its translated form by Maria Jolaswith a new forward by John R. Stilgoe. Secondary sources have also been of a great help in this research to facilitate the reading of Bachelard's philosophical ideas on space such as Robert Tally's Spatiality, and Neil Leach's Rethinking Architecture: A Reader in Cultural Theor

\section{Literature Review}

Some critics have mulled over the theme of memory and imagination in Never Let Me Go. For instance, Gurnham( 2016) introduces various literary works, amongst which is Kazuo Ishiguro's Never Let Me Go. He discusses the contrast between "'human' (ethical) and less than human (unethical) forms of procreating, living and dying" (p. 187). In doing so, Gurnham investigates how science fiction uses nostalgia to warn against the future of society. He explains the nature and general role of memory in Never Let Me Go, and how it is used to revive the loss of humanity in community. Gurnham establishes that "memory is unreliable and takes on a mythical, almost ghostly characteristic." (p.198). He elaborates this by discussing the 
"inadequacy" (p.198) and "unreliability" (p.199) of the students' memories of Hailsham. He even goes as far as arguing for the possibility that Hailsham "never existed outside its collective imagination." (p.198). In so doing, Gurnham emphasizes the significance of the memory of Hailsham in its students' imagination and the dynamics by which the story is structured.

Keeping with the same views on Memory, Teo (2014) examines the events of the story while focusing on the theme of memory. Teo explores memory's role in the students' lives, and how it functions as a coping mechanism for their loss of Hailsham. He further mentions that the world of Hailsham represents "the tranquility and innocence of their youth, and throughout the novel, the narrative is tinted with the memories of Hailsham; these memories stem not only from Kathy but from all of Hailsham's former students."(p.6)

Additionally, Teo (2014) accentuates the interrelated relationship between memory and Hailsham, describing it as "a site of memory that imbues their lives with a sense of collective identity" (p.131). He argues that the clones' collective memories of Hailsham serve as a revolt or "testimony" (p.129) against their death and erasure for "These memories are the clones' only real possessions" (p.134).

Furthermore, Cannella (2017) argues that the reader can only comprehend the novel by carefully analyzing the narrator's recount of memory and space. However, Kathy portrays memories and space in the novel that convert "non-urban space into a pseudo-cityscape" (p. 1). Besides, she argues that the novel consists of "unreliable natures of physical place and memory" (p.1), which means that memory and space unreliable. This shows that what memory conveys amounts to "a fragmented view of this post human society". (p.29) She further maintains that Kathy is not confident in the memories she has constructed, and, throughout the novel, she "prefaces her explanations with phrases of self-doubt."(p.116) However, Ishiguro imbues the places of the novel with a sense of authority, "allowing the reader to recognize the power of these places and thus construct a more complete narrative than the one Kathy is capable of offering."(p.116)

Cannella continues to suggest that the spatial information Ishiguro offers about Hailsham “ serves to complete Kathy's memories."(p.119). The nature surrounding Hailsham that counters the unnatural lives within Hailsham provides the reader with "a more stable, complete posthuman narrative than would be attainable with Kathy's memories alone."(p.119)From the criticism mentioned above, one could notice that the critics have notably indicated the effects of memory on structuring the characters' lives in Hailsham. However, none of them has meshed the theme of memory with the intimacy that Hailsham, as a space, embraces. Based on the ideas of Bachelard's spatial theory, this paper examines the deep ties between the characters and Hailsham as an intimate space.

\section{Analysis}

Bachelard investigates the delicate relationship between domestic space, or as Tally (2013) names it "the space of everyday life," (p.114) and the person inhabiting it. He focuses on two main aspects that are important in the making of authentic images: imagination and memory. He studies 
how imagination functions in relation to space, the way it fills it with spirit and sense, and, reversibly, the way space itself reflects and triggers emotions, memories and fantasy in the imagination of the inhabitant. The work of Bachelard is irresistibly pushed towards reviving memories those spaces that are manifest in one's mind. Bachelard conceptualized this idea in what he calls the poetic image. Thus, the work of an author is a manifestation of the relationship of memory, imagination and space, which is extensively described and detangled in Bachelard's spatial criticism that sheds light on the role of the physical sphere, particularly the house. Bachelard portrays the house by referring to it as "[a]community of memory and image" (Tally, 2013, p.49). It is not a mere physical placement in which the human being is simply a resident but more likely a holder of a deep level of consciousness.

Leach (1997) describes the house as "our first universe, a real cosmos of the world if we look at it intimately" (p.82). The house should be intimately felt; it is not a mere description of dimensions but a profound world that creates an open atmosphere for recapturing feelings. He likens the house to a nest, which is a place of security, peace and safety, and which protects the individual from the "hostility" and "aggressiveness" of the world (p.103). Many of our memories are housed ,especially if the house gives more details of its space.

One can retort to these memories through different forms of imagining, one of which is daydreaming. On his part, Bachelard introduces his conceptual approach in this context by referring to it as "Topoanalysis," which is "the systematic psychological study of the sites of our intimate lives" (p.8). This concept is linked with topophilia which is the act of loving a place. It is worth mentioning that Bachelard's theorization explores the notion of space from a psychological and cognitive level, which suggests a flexible reading to Never Let Me Go. Basing our interpretation on Bachelard's spatial views, the focus of this paper will be on the novel's engagement with the intimate space. It aims to explore the elements of intimacy in Hailsham that symbolize Bachelard's 'the oneiric house'. It equally investigates how daydream helps to retrieve memories in Hailsham as an intimate space.

\section{The Elements of Intimacy in Hailsham}

Bachelard's exploration of space emphasizes the intimacy it embraces in its interiority; every corner and object in an inhabited place refers to a particular meaning. The intimacy that space reflects helps memory and imagination to recapture alongside each other through certain things. For him, they are intimate tools that enable the individual's imaginative state to cope with his deep recollection. Read from this perspective, the memories, in Never Let Me Go, are highly aroused and linked to the present when the main character, Kathy, is more mature and aware of the intimate sense of space. She attempts to revive what makes sense for her in a lived space.

In the context of object appreciation, Kathy is frequently referring to a special building she called "the pavilion". The repetition suggests Kathy's impulse to bring attention to the place and to assert its significance. The pavilion functions as an escaping space and as a holder of the characters' secrets. It is a building that Kathy keeps on imagining on different ways and on numerous occasions from her memory of her close friends and the gossiping they continuously have, to the guardians who tend to keep on their eyes fixed on the students. In the first place, the 
pavilion reminds her of the way they escape their genuine and miserable reality; it is a warm place to be away from what reality imposes on them. The pavilion, as Kathy states, "had become the place to hide out with your best friends when you wanted to get away from the rest of Hailsham." (Ishiguro, 2005, p. 4) For her, the pavilion is a unique place away from the confines of Hailsham and the nest that she resorts to whenever she feels insecure. On the other hand, the pavilion does not only stand to typically function as an escaping space, but it also extends to her imagination as a refuge in which she feels the warmth, the freedom, and the comfort. Kathy says on this:

There was a kind of conversation that could only happen when you were hidden away in the pavilion; we might discuss something that was worrying us, or we might end up screaming with laughter, or in a furious row. Mostly, it was a way to unwind for a while with your closest friends. (p.5)

The pavilion is a space where Kathy and her friends can manipulate their small world and to expose their spirit and soul without being judged. Windows have always been interpreted in various symbolic forms, the most prominent of which is their transparent model of openness to the universe. The window is considered as the link that associates both the inside and the outside world; it triggers a break between the ordinary and the unordinary worlds.

Bachelard (1994) argues that the window is the way through which the individual examines the external world. Respectively, he states: "Through the window, the house converses about immensity with the world. And as metaphysicians would say, it too, the house of men, opens its doors to the world." (p.69) He asserts its importance in understanding what is beyond the eye. Never Let Me Go can be further scrutinized from Bachelard's perspective, suggesting a description of the window as the mirror of discovery and dreams. The window is one of the means to see the unseen, to reflect upon the personal thoughts and wander, and to surpass the imposed restrictions. Kathy, later on, says that "[there was] from almost any of the classroom, windows in the main house-and even in the pavilion" (Ishiguro, 2005, p.17). Given the opportunity to spiritually create a space of their personal managed world, windows, as Kathy alludes, represent their source of strength. Despite being surrounded by manipulative figures, this does not hinder the clone's independent thoughts to see the world differently. By creating a personally possessed world, the window does not only help to unleash thoughts but also to create new images that portray the world of one's own.

Kathy appreciates other important objects starting from the "collections" she gathered from the sales to the "Exchanges" they make from their handmade art. On the one hand, Kathy has revisited the days when she used to gather objects in order to possess her collection that is accumulated in a "wooden chest", a holder of privacy and secrets. Her possessions refer primarily to herself being independent from any other place and serve as a reminder of the precious value they add to her memories in Hailsham.

The collection of items, whenever remembered, recalls the nostalgia in Kathy's present when she says:"[in] Hailsham, you always find them, sooner or later, getting nostalgic about their collections" (Ishiguro,2005, p.19). These recollections are permanently inscribed in her memory 
because they hide a meaning; they are not mere tools for Kathy, but they portray series of emotional and meaningful representations of her personal choices and the wisdom of seeing things uniquely. However, for Ruth, it is quite the opposite as she is ready to keep her memory of Hailsham fixed in the past and carries on a new life. Therefore, in the context of embracing the meaningfulness of discrete objects, each character has a different perspective. Kathy deals with the items with fantasy as she does with the memory of her childhood home 'Hailsham'. Kathy emotionally deals with everything attached to her childhood as she considers it the central point where her life has been shaped. As for Ruth, she decides to abandon her childhood memory and to give a chance to the present to reshape her current life.

Kathy also talks about "Exchanges" that are usually the pieces of art they creatively make and exchange among them. She stresses their importance for all the clones, claiming: "Exchanges had a [stronger] effect on us all" (Ishiguro, 2005, p. 9). The Exchanges do not only communicate the material world, but, for her, they represent the exchange of ideas and thoughts that the person will, later on, realize in the future. For this, her appreciation of the meaning such physical world conveys contrasts with the way how Ruth perceives it. Ruth's decision to get rid of the "Exchanges" communicates her attempt to being careless about holding such meaningful items. Likewise, Kathy's faithfulness to her objects and the pleasure she receives from them underline the importance of her childhood memories. The Exchanges, from another side, estimate the students' sense of creativity, which teaches Kathy a sense of self-dependency. The assumption that the exchanges are granted by 'Madam' triggers Kathy and her friends to work harder and produce more creative objects. This could be a starting point to courageously make their own independent work and to represent a world they fantasize in their minds. The childhood possessions will come, later on, to inhabit Kathy's new space, opening a room for her to express her own vision of the world.

Bachelard(1994) shows interest in "an unfathomable store of daydreams of intimacy" (p.78), meaning objects in space like locks and drawers or, in the case of Never Let Me Go, collections, exchanges, and Kathy's cassette tape. The pre-mentioned material items help to conceptualize our perception of intimacy. Relatively, Bachelard argues that without them our lives would "lack a model of intimacy" (p.78). An example of this can be traced back to Kathy's early childhood and the influence of the Exchanges on her. The Exchange, Kathy explains, is:

A kind of big exhibition-cum-sale of all the things nnnn been creating in the three months since the last Exchange. Paintings, drawings, pottery; all sorts of "sculptures" made from whatever was the craze of the day-bashed-up cans, maybe, or bottle tops stuck onto cardboard. For each thing you put in, you were paid in Exchange Tokens - the guardians decided how many your particular masterpiece merited - and then on the day of the Exchange you went along with your tokens and "bought" the stuff you liked. (p. 9)

The Exchange communicates two central ideas. First of all, it shows how important material objects are for the students. Kathy states that it is the students' only way

Arab World English Journal for Translation \& Literary Studies 
Of building up a collection of personal possessions. If, say, you wanted to decorate the walls around your bed, or wanted something to carry around in your bag and place on your desk from room to room, then you could find it at the Exchange. (p.9)

This shows that the importance of these objects lies in the value they add to their individual spaces. Kathy mentions that Tommy is used to get bullied because of his inability to produce decent art. She theorizes that the resentment behind the bullying happens because Tommy does not contribute to the Exchange, which is seen as serious and crucial to everyone in the pavilion. This justifies why Kathy, later on, becomes such a devoted good carer with "a kind of instinct around donors." (p.3) She does her best to fulfill her duties towards others since the exchange functions as a model of intimacy that shapes her perception of life and behavior.

\section{Hailsham as 'the Oneiric House'}

Home provides an eternal memory. It stands for a domestic sphere that expresses both peace and comfort. Home is like a nest, as Bachelard described, since it gives the real sense of space and life; it protects the person from the evilness of the external world. Furthermore, Bachelard argues that our experiences in the childhood home never cease to accompany us through our adulthood, long after that home ceases to exist. Accordingly, Bachelard (1994) coins the term "oneiric house" (p.17). In the space that Bachelard calls 'the oneiric house', or childhood home, any place or corner in which a person hides or retreats from the outside world becomes "a place for solitude in the imagination" (p.136). This place, after functioning as a physical sanctuary to the individual for a long time, manifests its role in imagination. For Kathy and her friends, the pavilion has been their sanctuary in Hailsham, where they hide and release their emotions, laughter, gossip, anger ,and worry. Accordingly, Kathy mentions that : "the pavilion had become the place to hide out with your best friends when you wanted to get away from the rest of Hailsham." (p.5) It is where Kathy's emotions were set free and expressed safely in the company of her friends. Similar to the pavilion, Kathy mentions another place where she has isolated herself from her surroundings and has retreated back to her solitude, namely her favorite footpath. Notably, sanctuaries construct paths inside the characters' imagination in which they resurface whenever they are needed.

Bachelard(1994) states "the house remodels man" (p.47). According to this view, the characters' lives in Hailsham are carefully managed and structured. They seem at times robotic, lacking curiosity, critical thinking and any sense of resistance. They have never explored life outside, never questioned the things they were taught, and never revolted against the ideology of the teachers or guardians. Hailsham, being both their home and their school, has transformed each of them into a submissive model. Though the characters project different personalities and actions, none of them has attempted to break their designated mold and oppose any of the rules imposed on them. The characters' interests and personalities gradually change as they leave Hailsham and move to the cottages. The newly granted space comes with unprecedented freedom. Guardians are no longer around to impose rules of curfew or segregation.

Besides, boys and girls are allowed to go outside and to engage in sexual endeavors with no consequences or threats to their privacy. The characters, in being able to perceive themselves in 
new spaces, can also imagine themselves in new situations from different angles. In analyzing the character's transformed identity from one space to another, it is necessary to bring to light Bachelard's distinction between the concept of "the inside" and "the outside", and how the relationship between the two is inherently asymmetrical (pp.215-216). In this respect, Bachelard raises the question of where the individual ought to stand:

In this drama of intimate geometry, where should one live? ...The fear does not come from the outside. Nor is it composed of old memories. It has no past, no physiology. Nothing in common, either, with having one's breath taken away. Here fear is being itself. Where can one flee, where find refuge? In what shelter can one take refuge? Space is nothing but a "horrible outside-inside. (p.219)

The contemplation of which side to choose is concerned with constructing an identity, remodelling, growing up, fitting in, being flexible and, most of all, with gaining agency and responsibility over oneself. Kathy, when moving to the cottages, finds herself in a new space that requires her, in one way or another, to quit her old personality and come to terms with her new identity.

Furthermore, Tommy and Ruth have faced the question of who they are and how they choose to be perceived. These three characters show how the change in space affects their imagination and ,consequently, their identity. Ruth seems to display the most clear-cut break from her Hailsham identity by developing new fantasies and aspirations, by mingling with new people other than her Hailsham acquaintances, by going on an adventurous search for her possible in the outside world, and, perhaps the most notable indicator of this claim, by throwing away her collection from Hailsham when coming to the cottages. These actions show how Ruth, in comparison to Tommy and Kathy, is the most prominent example of choosing the outside. In other words, she is remodeled by the change in space choosing to adhere to the outside (cottages) and leaving the inside (Hailsham). Kathy holds on to Hailsham as she carefully explores herself and others in the cottages. Her approach is much more conservative and introverted in comparison with Ruth. Although Kathy has abandoned certain Hailsham traditions as her peers have done , like barging with Ruth and engaging in multiple sexual relations with random people at the cottages, she still observes and analyzes her friends' behaviors passively until she decides to depart. On the other hand, Tommy portrays an interesting mixture of the two girls' attitudes

Bachelard (1994) believes that our imagination functions in coordination with the structure of the house. He explains this with the idea of the polarity between the "cellar" and the "attic" and how our mind functions in a way that mimics the "vertical polarity" of the two. (p.18) He further argues, while crediting Carl Jung's work, that when a person encounters a disturbing sound coming from the cellar, he rushes to the attic to try to figure out what the sound is instead of investigating the cellar. This means that when a dark thought occupies our mind, the brain tries to make sense of it in a superficial way rather than assessing it in its full meaning. This idea is depicted in the novel when the characters as young as thirteen years old, have known that one day they will have to be devoided of their own organs. 
As terrifying as the idea sounds, Kathy does not mention emotions of fear or terror, but instead, the characters cope with this fate with humor. Kathy recalls, in a chilling calmness, how Tommy's incident has developed into a running joke about how they will all one day unzip their bodies and offer their organs "as some way of acknowledging what was in front of us." (Ishiguro,2005, p. 43) The contrast between how dark the idea of unzipping is and the fact that they use humor in dealing with it is a reflection of Bachelard's idea of the cellar and the attic. Instead of facing the idea of donations and of allowing themselves to process their feelings on it, they choose to superficially deal with it by treating it like a joke. In a way, the characters' reaction can be seen as a coping mechanism to deal with their suffering.

\section{Day Dreaming}

Daydreaming proves to work unconditionally alongside the memory of a certain space; it offers a way to fantasize a series of previous experiences. Daydreaming takes place whenever the person comes across a memory that reminds him of the parallel point he met in the past. Thus, this aspect provides a sense of a place to the individual who has inhabited it.

The emotional influence of a space extends to the future and manifests itself in a form of daydream as Bachelard(1994) claims: "the daydream deepens to the point where an immemorial domain opens up for the dreamer of a home beyond man's earliest memory." (p. 5) In parallel with this, Kathy sometimes turns to daydreaming in order to recapture the memories of Hailsham and to reflect upon her admiration of the place she is still affectionate about. For her, the story about Hailsham is the essential source of her entire life. It is also the only thing that triggers her feelings, taking her back to the past and giving her the chance to make sense of her memories. Due to her uncontrollable efforts of imagining Hailsham, Kathy comes to realize the failure of her manipulative mindset, which is evident in her present life. In one of her words, she claims: "maybe that's it! I've found it! This actually is Hailsham!" Then I see it's impossible and I go on driving, my thoughts drifting on elsewhere" (Ishiguro, 2005, p. 4). Regardless of the transformational phase she has been through, Kathy still appears unable to determine her location to suggest where things are. She is disturbed between both the private and public spaces. The only thing that familiarizes her with her location is her conscious awakening. Hailsham, regarding Bachelard's ideas, functions as Kathy's childhood home, the one that she carries along in her imagination for the rest of her life, and the one that influences her imagination, memory and daydreams in countless ways.

Bachelard(1994) suggests that "childhood is certainly greater than reality. Our attachment for the house we were born in, in dream, is more powerful than thought." (p.16) Accordingly, the reader witnesses how it is Hailsham that affects Kathy and the characters more than any other spaces. Kathy mentions that she, for years, has resisted the urge to remember Hailsham; however, when she encounters the donor who brings those memories to the surface of her imagination, she notes that his obsessive curiosity with Hailsham is a way to re-imagine his own past and to daydream of a different reality than his own.

\section{Discussion}

Memory and imagination are the components by which space is revived. Space, most specifically, the childhood home, works interchangeably with memory and imagination as they affect each 
other with the lapse of time. Regardless of what the pre-mentioned critics argued about the attachment of the characters to Hailsham memories, this paper underscores the impact of both imagination and memory on the characters' changing perception of reality. They have the power to change their perception of reality as well as their understanding of the environment and the people around them. The motif of rumors and the spread of false information as truth resonate in the novel. In fact, one could argue that both imagination and memory drive the entire story to the extent that it sometimes dictates some of the characters' most important decisions and expectations. Throughout the story, the characters construct and manipulate their reality through imagination and memory. They end up finding difficulties to distinguish between their theories and the infinite possibilities to the scenarios they make, putting into practice what Bachelard(1994) calls 'disguized imagination' as described in what follows: "...I wonder if an image of the imagination is ever close to reality. For often when we think we are describing we merely imagine." (p.120)

The characters fill gaps in their knowledge of their surroundings with assumptions, rumors and false hope. The story about the purpose behind madam's gallery, the myth of the deferrals, the myth of the woods, the void gestures of public display of affection and fake intimacy, the fantasies surrounding Miss Lucy and, finally, Ruth's story with the pencil case are examples of how the characters use imagination to experience a different reality. Most often, these cases start as theories attempting to investigate the unknown since the characters are too passive to directly require answers from the subjects in question. Instead, what these situations lead to is false hope, wasted time and energy, and a blurred line between what is real and what is not.

The physical aspect that connects humans with life is their body. Once they have no control or agency over it, it becomes a dead body. By being restricted to the boundaries and rules of Hailsham, Kathy along with others have no option but to embrace their already -shaped reality from their day of birth. Their bodies are created to serve human beings through organ donation; neither their lives nor their sense of existence matters. Even though they are raised in a wellestablished institution, they must inevitably arrive at their fate of "completion". One can say that their life with all its difficulties and facilities is shortened to a life mission. The clones , in this case, are assigned to complete their mission by donating their organs in a series of fragmented missions related to certain periods of their lives. Nearing his completion with the fourth donation, Tommy tells Kathy: "You know why it is, Kath, why everyone worries so much about the fourth? It's because they're not sure they'll really complete. If you knew for certain you'd complete, it would be easier. But they never tell us for sure" (Ishiguro, 2005, p. 137). Tommy expresses the shredding anxiety that comes with the process of dying. The clones are forbidden from complaining about their fixed ending despite the fear they experience towards it. Here, imagination and memory act as a savior as they create a false hope for an unfounded rumor. The deferrals spark Kathy and Tommy's curiosity since the two hopelessly try to deal with their fear of completion. They seek the truth behind the deferrals by meeting madam only to find out that their hope for salvation is nothing but a work of imagination.

Arab World English Journal for Translation \& Literary Studies 


\section{Conclusion}

Kazuo Ishiguro's Never Let Me Go(2005) presents a fertile ground for investigating the interrelatedness of space, memory and imagination according to Bachelard's spatial philosophy. Throughout this study, one may notice that space becomes no longer a static and empty component, but it turns to be relative and dialogical since it goes beyond the physical geography by offering a dialogue between different dynamic disciplines like sociality, history, psychology and others. Bachelard(1994) supplies the reader with a cognitive and psychological reading of space by emphasizing the interplay of memory and imagination in some intimate spaces such as the house. Through Kathy's narration, the reader may find out that the novel takes a psychological dimension by evoking the characters' memories in the space of Hailsham, the fact that makes it a suitable material for Bachelard's theorization.

Memory as communicated in the novel of Never Let Me Go exemplifies what Bachelard introduces in his Poetics of Space. According to what Bachelard emphasizes in terms of memory by association, the objects as elements of intimacy take the role of a mediator between the accumulated experiences and the intimate space as it is the case with Kathy. Regarding Bachelard's idea of the inside and the outside, choosing where to stand is a question of identity. Memory functions in coordination with the structure of the oneiric house; the concept of the cellar and the attic goes in parallel with the way the mind handles deep and superficial thoughts. As an example, the characters deal with the donations in the attic of their minds through humor. Briefly, Bachelard's ideas on memory and imagination suggests a deep level of psychological analysis that fits to what Ishiguro attempts to portray in his novel that memory is revived and housed.

\section{About the Authors:}

Dr. Soumaya Bouacida is an assistant professor of English Literature at Skikda University in Algeria. She has got her Ph.D. degree in English Literature from the University of Jordan. She is interested in postmodern studies, postcolonial literature and African American literature. She has participated in some international conferences and has published some interesting papers on postmodernism, African American studies, food studies and classical literature in different Journals such as Critical Survey and Jordan Journal of Modern Languages and Literature.ORCID ID: https://orcid.org/0000-0002-8758-1295

Dr. Ikram Lecheheb is an assistant professor at Skikda University, Algeria. She got her Ph.D. from the University of Jordan. She has interests in Arabic literature, English Literature, Diaspora, Ethnicity, Identity Studies, and Trauma Studies. She has published an article entitled "Hearing Voices: A Corporeal Expression of Trauma in Margaret Atwood's Lady Oracle" and participated in various international conferences.ORCID ID: https://orcid.org/0000-0001-76052649

Itidel Boumalit is an independent scholar. She got her MA degree in English Literature from the University of Skikda, Algeria. She is interested in modernism, postmodernism and space studies. ORCiD ID: https://orcid.org/0000-0002-8758-1295 
Nada Khlifa is an independent scholar. She got her MA degree in English Literature from the University of Skikda, Algeria. She is interested in modernism, Realist Literature, postmodernism and space studies. ORCiD ID: https://orcid.org/0000-0003-2169-5051

\section{References}

Bachelard, G. (1994). Poetics of Space(J. R. Stilgoe\& M. Jolas, trans.). Boston:Beacon Press. Cannella, M. E. (2017). Unreliable Physical Places and Memories As Posthuman Narration in Ishiguro's Never Let Me Go. Sanglap: Journal of Literary and Cultural Inquiry, 3(2), 1 29. Available at http://sanglap journal.in/index.php/sanglap/article/view/61.

Gurnham, D. (2016). Memory, Imagination, Justice: Intersections of Law and Literature. London: Routledge.

Ishiguro, K. (2005). Never Let Me Go. London: Faber and Faber.

Leach, N. (1997). "Gaston Bachelard: Poetics of Space" in Neil Leach, ed., Rethinking Architecture: A Reader in Cultural Theory(pp. 98-109 ).London: Routledge.

Teo, Y.(2014). "Testimony and the Affirmation of Memory in Kazuo Ishiguro's Never Let Me Go." Critique: Studies in Contemporary Fiction, 55(2), 129-134.Available at https://doi.org/10.1080/00111619.2012.656209.

Tally J. R. T. (2013). Spatiality. London: Routledge. 